PACS: $28.41 . \mathrm{Te}$

\title{
CHANGE OF QUALITY OF A RADIOACTIVE WASTE UNDER LONG STORE TERMS
}

\author{
M.S. Malovytsia, S.A. Pismenetskiy, G.S. Hrushch, O.P. Shchus \\ V.N. Karazin Kharkiv National University \\ 4 Svobody Sq., Kharkov, 61022, Ukraine \\ e-mail:.jcm2027@gmail.com, tel: +38 (066) 990-69-92 \\ Received March 2, 2018
}

By calculation methods, the dose rate of the radioactive waste, behind concrete protection, was evaluated in current work. Parameters, which were taken in account in the calculations, are geometry of the protection shell, size of the source and its isotopic composition. As model geometrical parameters the spent fuel assembly's size and thickness of the concrete wall of the ventilated storage container (VSC)-VVER were taken. The computer program that does numerical calculation was composed in the Wolfram Alpha environment. The program takes into account change of the isotopic composition and spectra of gamma-radiation with time. Calculation results were compared to the known data on the spent nuclear fuel heat dissipation. Approach described in this work can be used for fast estimation of change in the quality of radioactive waste (RAW) in the long-term storage without recycling, for different initial isotopic composition. Obtained results were analyzed on the matter of change in gamma-radiation of RAW.

KEYWORDS: radioactive waste, dose rate, long terms storage, concrete protection, isotopic composition

\section{ЗМІНА ЯКОСТІ РАДІОАКТИВНИХ ВІДХОДІВ ПРИ ДОВГОСТРОКОВОМУ ЗБЕРІГАННІ \\ М.С. Маловиця, С.О. Письменецький, Г.С. Хрущ, О.П. Щусь \\ Харківський наиіональний університет імені В.Н. Каразіна \\ 61022, Україна, м. Харків, пл. Свободи, 4}

В цій праці чисельними методами розраховувалась потужність дози випромінювання радіоактивних відходів за бетонним захистом. При розрахунках враховувалася геометрія захисної оболонки, розмір джерела та його ізотопний склад. В якості модельних геометричних параметрів були взяті розміри відпрацьованої тепловиділяючої збірки (ВТВ3) та товщина бетонного контейнера зберігання, що провітрюється (КЗП)-ВВЕР. Для проведення чисельних розрахунків, в середовищі Wolfram Alpha була складена комп'ютерна програма. В програмі враховується зміна ізотопного складу відпрацьованого ядерного палива 3 часом та зміна енергетичного спектру гамма-випромінювання. Проведено порівняння результатів розрахунків $з$ даними по тепловиділенню відпрацьованого ядерного палива (ВЯП). Методика, що використовувалась, дозволяє проводити швидку оцінку зміни якості радіоактивних відходів (РАВ) при довгостроковому зберіганні без переробки, при різному початковому ізотопному складі палива. За результатами розрахунків був проведений аналіз зміни гамма-випромінювання РАВ.

КЛЮЧОВІ СЛОВА: радіоактивні відходи, потужність дози, довгострокове зберігання, бетонний захист, ізотопний склад

\section{ИЗМЕНЕНИЕ КАЧЕСТВА РАДИОАКТИВНЫХ ОТХОДОВ ПРИ ДОЛГОВРЕМЕННОМ ХРАНЕНИИ}

М.С. Маловица, С.А. Письменецкий, Г.С. Хрущ, А.Ф. Щусь

Харьковский начиональный университет имени В.Н. Каразина 61022, Украина, г. Харьков, пл. Свободы, 4

В данной работе численными методами рассчитывалась мощность дозы излучения радиоактивных отходов за бетонной защитой. При расчётах учитывались геометрия защитной оболочки, размер источника и его изотопный состав. В качестве модельных геометрических параметров были взяты размеры отработанной тепловыделяющей сборки (OTBC) и толщина стенки бетонного вентилируемого контейнера хранения (BКX)-ВВЭР. Для проведения численных расчётов, в cpeде Wolfram Alpha была составлена программа. В программе учитывается изменение изотопного состава отработанного ядерного топлива со временем и изменение энергетического спектра гамма-излучения. Проведено сравнение результатов вычисления с известными данными по тепловыделению отработанного ядерного топлива (ОЯТ). Используемая методика позволяет проводить быструю оценку изменения качества радиоактивных отходов (РАО) при долговременном хранении без переработки, для различных изотопных составов топлива. По результатам расчётов был проведён анализ изменения гаммаизлучения РАО.

КЛЮЧЕВЫЕ СЛОВА: радиоактивные отходы, мощность дозы, долгосрочное хранение, бетонная защита, изотопный состав

Production and accumulation of the radioactive waste (RAW) are one of the major problems associated with the use of nuclear energy in any of its forms. According to the existing data, there is about 300 thousand tons of accumulated spent nuclear fuel (SNF) with total activity of $\sim 10^{20} \mathrm{Bk}$, and by year 2030 , this quantity is predicted to be 500 thousand tons. In particular, importance of this problem is reflected by the fact, that in the last years several monographs [1-5] on the problems of dealing with RAW were published.

Leaving aside the cosmic origin and associated with uranium mining radionuclides, in this paper we will consider 2 forms of RAW: 1) contained in SNF; 2) the so-called operational waste of nuclear plant. According to the established terminology, in countries, where radiochemical or other recycling is not intended (for example - Ukraine), it belongs to the high-level RAW (HLW). 
Currently, from 32 countries, oriented at nuclear power, 11 are developing radiochemical recycling, 6 - designing geological burial of SNF and HLW, and the rest (including Ukraine) implementing a temporary solution, consisting in the organization of temporary (30-100 years) safe storage of radioactive waste (spent fuel) without processing [3].

The composition of the radionuclides SNF studied in sufficiently detailed and is found in most nuclear databases. The composition of the radionuclides of the operational RAW is determined by the set of measures used on the nuclear plant for isolating, quite widely varies with time and treatment technology (recycling) [3].

Due to the currently accepted procedure of transformation of physical and chemical forms, and the isotopic composition of RAW, of particular interest is to trace the properties of the RAW(SNF) and other - solid radioactive waste (SRW) and liquid radioactive waste (LRW), for long-term storage without further processing.

The purpose of this work - to track changes in the quality of stored RAW for the first 30-50 years, and on this basis assess the possibility of improving the technology of handling RAW. Of particular interest in this case is the cooling interval 3-10 years, when overload, certification, and sorting operations are being done and there is possibility of operations with open SNF.

PROPERTIES OF THE RADIOACTIVE WASTE QUALITIES

Following the recommendations of [6] by a quality of waste (spent nuclear fuel) we mean the following criteria for storage and disposal: the total activity, radionuclide composition and specific activity, the equivalent dose rate, the energy release, the content of nuclear (fissile) materials, other physical and chemical parameters. For the standard SNF these parameters are presented on Fig. 1,2.

\section{Energy release}

Energy release of spent fuel was investigated from the very first years of operation of the reactors.

Way and Wigner (1946) published a formula for calculating the energy release up to the $10^{5}$ seconds [7], which was used until the 70s. In 1963 B.G. Pologikh [8] proposed to modify the formula and extend its validity up to $10^{8}$ seconds (3 years). McNeir [9] published the most accurate experimental results of residual heat release and offered their approximation as integral and series with tabulated coefficients.

Modern data on heat generation of WWER SNF [10] are consistent with other known settlements within $\pm 10 \%$ (with the oldest $(+28 /-19) \%$ ) and made valid until the times of $\sim 10^{8}$ seconds.

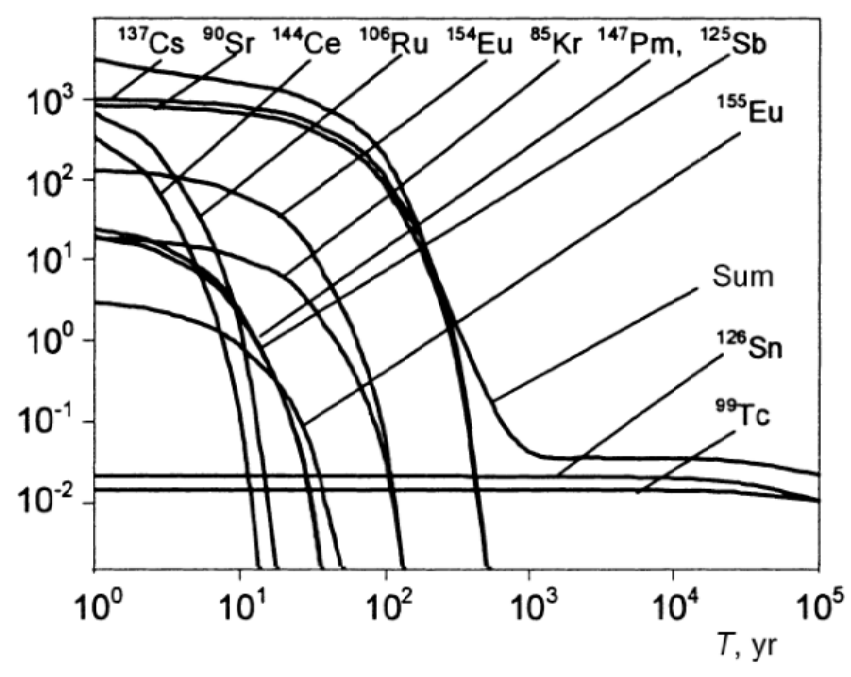

Fig. 1. Energy release of the SNF during long term storage without recycling [11].

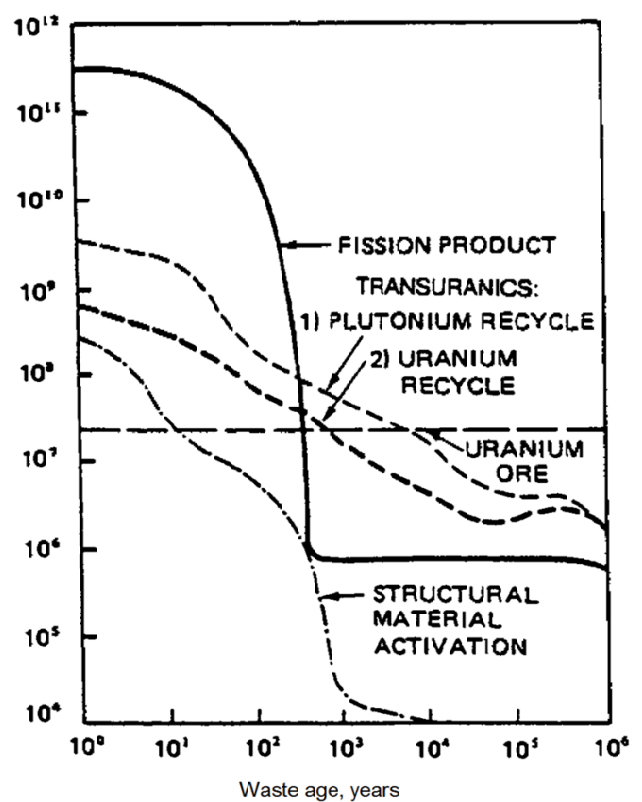

Fig. 2. Index of danger or the relative toxicity of the radioactive products of SNF (quantity in $\mathrm{m}^{3}$ of water to bring it to the allowable concentration) [11]

\section{Total activity and dose rate}

In this article, the total activity of the source does not affect the result, lets consider the initial time it is equal to 1 . Since in RAW there are several different isotopes, the total activity is the sum of activities.

Hereinafter, $\mathrm{j}$ - denotes the number of isotopes in the mixture.

Since activity of the individual isotope decays exponentially, the total activity decreases as the sum of exponents. 
The calculation uses the percentage value of the contribution to the total activity of the isotope source at a time

$$
a_{j}=\frac{A_{j}(t)}{A(t)}
$$

Renormalizing condition according to (1)

$$
\sum_{j} a_{j}=1
$$

Data on the total activity of SNF and its behavior were investigated and presented in [12]. The dose rate can be calculated based on the isotopic composition.

\section{CALCULATION OF GAMMA-CONSTANT Rationale for a common approach}

When working with the real sources of ionizing radiation such as SNF four factors should be accounted for: 1) the geometry of the problem, 2) self-absorption in the source, 3) the effect of shielding, 4) the isotopic composition of the emitter. Since the isotopic composition of the radionuclide mix changes over time, factors 2 and 3 does not remain constant. In this context, it is convenient to use, as a characteristic of the source, a generalized gamma constant (GGC) $[13,14]$, which takes into account the self-absorption in the volume source and the possible presence of protection and is numerically equal to the ratio of gamma-radiation at the observation point to the activity of the source. Generalization means that in calculations several factors are accounted for such as different radioisotopes in the sources, each with its differential gamma constant and account self-absorption in the body of the source and possible protective screen, absorption of which different for each energy of radiation.

As a model for the calculation of the source fragment of the standard VVER-1000 has been selected, presented in the form of a cylinder with diameter of $250 \mathrm{~mm}$ and height of 2.5 meters with the closest to the real filling, consisting of $322 \mathrm{~kg}$ of uranium dioxide, $109 \mathrm{~kg}$ of zirconium and $14 \mathrm{~kg}$ of steel, located in the air. The disposition of fuel and concrete protection is shown on the Fig. 3.

Radionuclide composition of the SNF was taken according to $2000 \mathrm{y}$. [15] data and is given in Table 1 below. There are also differential values of gamma constant of the radionuclides components.

The composition of fission products from Table 1 after 3 years of aging was selected for calculation. For smaller aging time the SNF data was not considered because the problems, discussed in this article, related to the quality of the radiation protection of the concrete, where the fuel is stored after 3 years of aging. Another reason is the intense radiation of short-lived isotopes in fresh spent fuel, making it difficult to measure its composition.

Table 1.

The initial isotopic composition SNF [15]

\begin{tabular}{|l|c|l|}
\hline Isotope & Activity $\%$ & $\Gamma, \mathrm{aGy} \times \mathrm{m}^{2} /(\mathrm{s} \times \mathrm{Bq})$ \\
\hline${ }^{90} \mathrm{Sr}$ & 19,20 & $7,85 \mathrm{E}-07$ \\
\hline${ }^{106} \mathrm{Ru}$ & 16,95 & $7,48 \mathrm{E}+00$ \\
\hline${ }^{134} \mathrm{Cs}$ & 7,25 & $5,76 \mathrm{E}+01$ \\
\hline${ }^{137} \mathrm{Cs}$ & 26,29 & $2,11 \mathrm{E}+01$ \\
\hline${ }^{144} \mathrm{Ce}$ & 18,55 & $5,28 \mathrm{E}-01$ \\
\hline${ }^{147} \mathrm{Pm}$ & 9,65 & $1,06 \mathrm{E}-04$ \\
\hline${ }^{85} \mathrm{Kr}$ & 0,77 & $8,43 \mathrm{E}-02$ \\
\hline${ }^{154} \mathrm{Eu}$ & 0,74 & $4,34 \mathrm{E}+01$ \\
\hline${ }^{155} \mathrm{Eu}$ & 0,61 & $1,57 \mathrm{E}+00$ \\
\hline
\end{tabular}

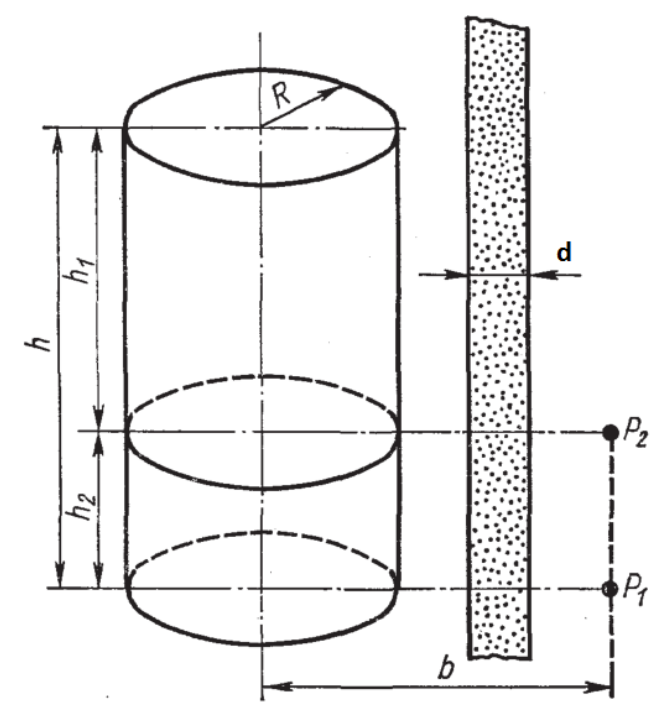

Fig. 3. Geometry for computation [12]

The attenuation coefficient for concrete protection can be taken from known tables. And the attenuation coefficient due to self-absorption for the spent fuel assembly (SFA), consisting of several components with total amount of (uranium $-450 \mathrm{~kg}, 55 \mathrm{~kg}$ oxygen and zirconium $200 \mathrm{~kg}$ ). For calculations instead of zirconium the data for attenuation coefficient were taken for the nearest element with known tables of absorption coefficients, in this case molybdenum. It was assumed that these elements are distributed uniformly over the volume. Accordingly, knowing the density of each element and the mass attenuation coefficient [13] it is possible to calculate the total linear attenuation coefficient.

\section{Method of calculation of the GGC}

The dose rate of gamma radiation was calculated by the standard method [13] at the point opposite the midcylinder power at a distance of $1 \mathrm{~m}$ from its axis, also with placing concrete wall with thickness of 30 or $60 \mathrm{~cm}$ between 
the source and the observation point. Gamma constant of the $\mathrm{j}$-th isotope containing several gamma lines can be calculated as follows:

$$
\Gamma_{\mathrm{j}}=\sum_{i} n_{j i} \Gamma\left(E_{j i}\right)
$$

where $\Gamma\left(E_{j i}\right)$ - gamma constant for a certain line of energy $n_{j i}$ - quantum yield of photons of a given energy. Here, $\mathrm{j}$ - the index of the isotope in the mixture, $\mathrm{i}$ - the index of the gamma line.

Total dose rate of a mixture of isotopes can be expressed as:

$$
\dot{G}=\sum_{j} \dot{G}_{j}=\sum_{j} \frac{\Gamma_{j} A_{j}}{r^{2}}
$$

where $j$ is the index of isotope, $r$ is the distance from the source to the observation point.

Generalized gamma constant - the ratio of gamma radiation and the activity of A at a distance $\mathrm{r}$, which can be written as follows:

Substituting in (6) the expression (5) yields:

$$
\Gamma=\frac{\dot{G} r^{2}}{A} .
$$

$$
\Gamma=\sum_{j} \frac{A_{j}}{A} \Gamma_{j}
$$

This expression was used by us to calculate the GGC for ideal point source.

For the volume cylindrical source dose rate calculated according to [13]:

$$
\dot{G_{j l}}=2 \frac{A_{j i}}{V} \Gamma_{\mathrm{i}} R G_{j i}\left(\frac{h}{R}, \frac{b}{R}, \mu_{s}\left(E_{j i}\right) R, d \mu\left(E_{j i}\right)\right),
$$

here $h$ is the height of the cylinder, $b$ is the distance from its axis to the observation point, $\mathrm{R}$ is the radius of cylindrical source, and $\mathrm{d}$ is the thickness of the protection screen.

Reduction factors for self-absorbing cylinder $\left(\mu_{s}\right)$ and protection $(\mu)$ depends on the energy of photons, therefore, the dose must be calculated separately for each gamma line. The total dose rate - the sum of the partial dose powers.

For radiation of one isotope, we have:

$$
\dot{G}_{J}=\sum_{i} \dot{G}_{j i}=\sum_{i} 2 \frac{A_{j i}}{V} \Gamma_{j i} R G_{j i}\left(\frac{h}{R}, \frac{b}{R}, \mu_{s} R, d \mu\right) .
$$

And GGC of the self-absorbing cylinder with one emitting isotope with a protective screen we get:

$$
\Gamma_{\mathrm{j}}=\frac{G_{j} r^{2}}{A_{j}}=\sum_{i} 2 \frac{A_{j i}}{A_{j}} \Gamma_{j i} \frac{R r^{2}}{V} G_{j i}=\sum_{i} 2 n_{j i} \Gamma_{j i} \frac{R r^{2}}{V} G_{j i} .
$$

As you can see, this value does not vary with time as it does not contain time dependent arguments.

For GGC isotope mixture, the total activity A can be obtained:

$$
\begin{array}{r}
\dot{G}=\sum_{j} \dot{G}_{j}=\sum_{j} 2 \frac{A_{j}}{V} \Gamma_{j} R G_{j} . \\
\Gamma=\sum_{j} 2 \frac{A_{j}}{A} \Gamma_{j} \frac{R r^{2}}{V} G_{j} .
\end{array}
$$

In this expression activity and gamma constant of individual elements are multiplied, making it impossible to separate them into two separate sum (sum of the activities and the amount of gamma constant). In this case, the value of the GGC is time dependent because for different isotopes half-life is different, thus the percentage $\frac{A_{j}}{A}$ contribution of the $\mathrm{j}$-th mixture isotope will vary.

Expression (12) was used to calculate the generalized gamma constant (GGC) cylindrical self-absorbing source with protection.

\section{The results of calculations of external radiation SNF}

Authors have developed a unique computer program, which calculated gamma constant according to the eq. (12). The decay of the SNF isotopes was also taken inti account as a change to the energy distribution of the gamma spectrum.

Fig. 4,5 show the calculated dependence of the GGC versus time for an ideal point source and a source with selfabsorption accordingly. Accounting for self-absorption in the source characterizes the heat release caused by gamma radiation of the SFA. Obtained GGC is consistent with the data from [11], if the activity is calculated for the data of the Table 1. Also, from this graph, you can conclude that the dose rate of the ideal source decreases slower than activity with time the first five years, and then decline is at the same speed. This is due to the rapid depletion of the isotopic composition of gamma emitters in the first 3-5 years of age and accompanied by an increase of GGC. Values of the GGC curve on Fig. 5 about an order of magnitude smaller than on Fig. 4 due to self-absorption power. Also, this graph proves the rule, which says that the total activity of the SNF mixture the first 30 years is decreasing faster than the decay heat. 
The result of the calculation model of the GGC source with self-absorption and the flat protection of concrete 30 $\mathrm{cm}$ and $60 \mathrm{~cm}$ is shown on Fig. 6,7. Having a shield leads to a weakening of the flow of low-energy photons, which are dominating in spectrum at the beginning of decay and after 30-40 years of aging. The observed peak is formed mainly from emissions of the ${ }^{134,137}$ Cs. The first five years of constant GGC is growing rapidly, due to the decay of the lowenergy sources, and then falls down as exponent. From this we can conclude that the weakening multiplicity of gammaradiation of protective storage container increases with time. At the same time, Fig. 7 reflects the fact that the dose rate of external radiation of SNF decays faster than its activity. For convenience the calculation results for the GGC are presented in the Table 2 .

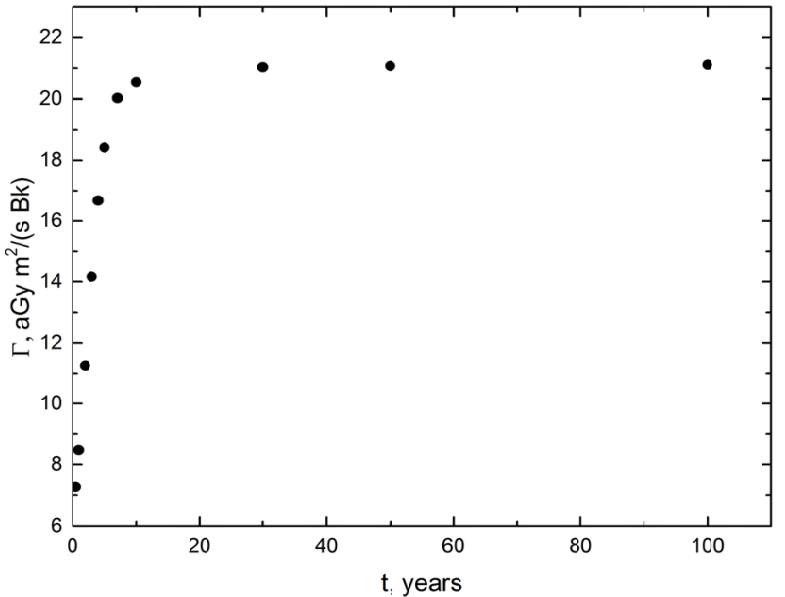

Fig. 4. Point source's GGC without protection

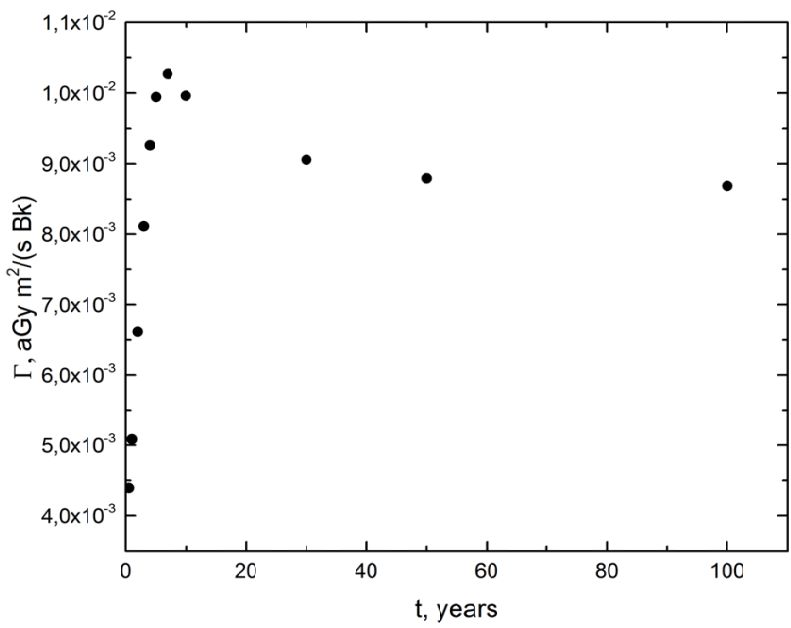

Fig. 6. GGC for source with protection $30 \mathrm{~cm}$

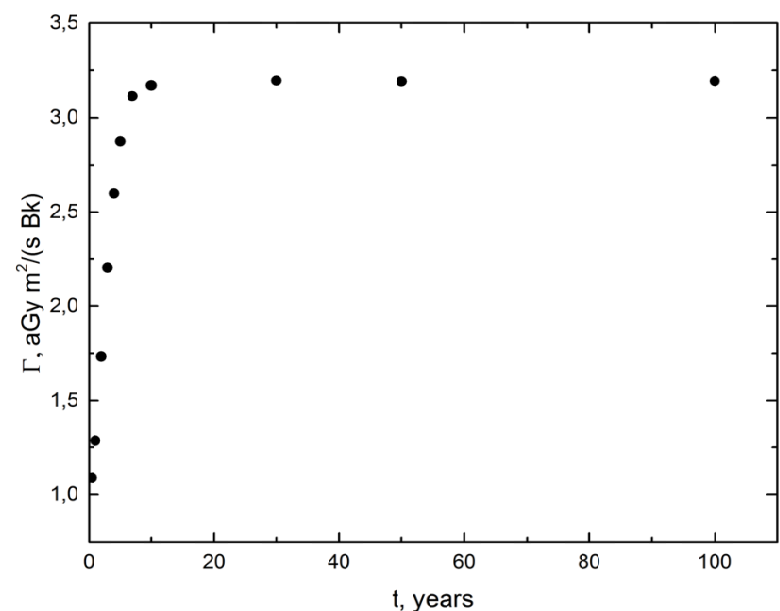

Fig. 5. Self-absorbing cylindrical source's GGC without protection

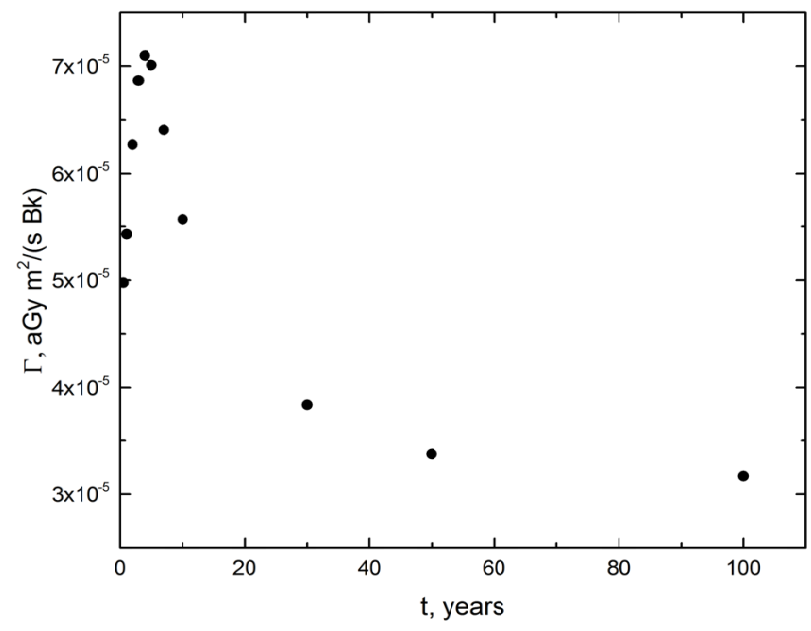

Fig. 7. GGC for source with protection $60 \mathrm{~cm}$

Table 2

GGC values for different source configurations

\begin{tabular}{|r|c|c|c|c|}
\hline \multicolumn{1}{|l|}{$\begin{array}{l}\text { SNF age, } \\
\text { yrs }\end{array}$} & Point source & $\begin{array}{c}\text { Cylindrical source without } \\
\text { protection }\end{array}$ & $\begin{array}{c}\text { Cylindrical source with flat } \\
\text { protection wall d=30 cm }\end{array}$ & $\begin{array}{c}\text { Cylindrical source with flat } \\
\text { protection wall d=60 cm }\end{array}$ \\
\hline 0,5 & $7,2726 \mathrm{E}+00$ & $1,0888 \mathrm{E}+00$ & $4,3915 \mathrm{E}-03$ & $4,9752 \mathrm{E}-05$ \\
\hline 1 & $8,4748 \mathrm{E}+00$ & $1,2842 \mathrm{E}+00$ & $5,0839 \mathrm{E}-03$ & $5,4276 \mathrm{E}-05$ \\
\hline 2 & $1,1255 \mathrm{E}+01$ & $1,7347 \mathrm{E}+00$ & $6,6156 \mathrm{E}-03$ & $6,2688 \mathrm{E}-05$ \\
\hline 3 & $1,4170 \mathrm{E}+01$ & $2,2040 \mathrm{E}+00$ & $8,1097 \mathrm{E}-03$ & $6,8649 \mathrm{E}-05$ \\
\hline 4 & $1,6668 \mathrm{E}+01$ & $2,6018 \mathrm{E}+00$ & $9,2640 \mathrm{E}-03$ & $7,0978 \mathrm{E}-05$ \\
\hline 5 & $1,8422 \mathrm{E}+01$ & $2,8757 \mathrm{E}+00$ & $9,9453 \mathrm{E}-03$ & $7,0088 \mathrm{E}-05$ \\
\hline 7 & $2,0028 \mathrm{E}+01$ & $3,1129 \mathrm{E}+00$ & $1,0270 \mathrm{E}-02$ & $6,4057 \mathrm{E}-05$ \\
\hline 10 & $2,0545 \mathrm{E}+01$ & $3,1690 \mathrm{E}+00$ & $9,9639 \mathrm{E}-03$ & $5,5656 \mathrm{E}-05$ \\
\hline 30 & $2,1026 \mathrm{E}+01$ & $3,1942 \mathrm{E}+00$ & $9,0585 \mathrm{E}-03$ & $3,8407 \mathrm{E}-05$ \\
\hline 50 & $2,1073 \mathrm{E}+01$ & $3,1902 \mathrm{E}+00$ & $8,7979 \mathrm{E}-03$ & $3,3732 \mathrm{E}-05$ \\
\hline 100 & $2,1113 \mathrm{E}+01$ & $3,1912 \mathrm{E}+00$ & $8,6897 \mathrm{E}-03$ & $3,1683 \mathrm{E}-05$ \\
\hline
\end{tabular}




\section{CONCLUSION}

To produce the best technology of radioactive waste (SNF) management, accurate and reliable information on the properties of the SNF during prolonged storage is needed. Accumulated to date, research results and authors' assessments allows to establish some laws relating to the physical properties of the RAW (SNF) for long-term storage without recycling. Approach of the GGC proposed by the authors to assess the quality of RAW (SNF) proved effective and showed characteristic changes in the quality of spent nuclear fuel. It is, first of all, the backlog in decrease of activity from the decrease of the energy release and dose power of radiation, then the establishment of the equilibrium spectrum and exponential decay of dose power of $\gamma$-rays, and, finally, reducing the role of radiation fission products and actinides dominance radiation after 30-50 years of aging.

Unique computer program that calculates SNF gamma radiation parameters was developed. The program takes into account isotope decay, geometry of the source, and concrete protection.

In this paper, for various reasons of such an important factor in assessing the quality of spent nuclear fuel as the neutron radiation, especially for spent nuclear fuel with a high level of burnout, remained outside the consideration. Along with the problem of dealing with nuclear operating waste these questions waiting for the optimal solution.

\section{RFERENCES}

1. Nosovsky A.V., Vasilchenko A.N., Klyuchnikov A.V., Yaschenko Ya.V. Ed. A.V. Nosovsky. Snyatie s ekspluatacii jadernyh energeticheskih ustanovok. Seria: Safety of nuclear power plants. [Decommissioning of nuclear power plants]. - K.: Tehnika, 2005. - 288 p. (in Russian)

2. Nosovsky A.V., Vasilchenko A.N., Pavlenko A.A., Pismenny E.N., Shirokov S.V. Ed. A.V. Nosovsky. Vvedenie v bezopasnost' yadernyh tekhnologij. Seria: Safety of nuclear power plants. [Introduction to the safety of nuclear technology]. K: Tehnika, 2006.-268 p. (in Russian)

3. Azhazha V.M., Belous V.A., Habelkov H.V., Dzhur Ye.O., Krykun Yu.O., Levenets V.V., Lysychenko H.V., Neklyudov I.M., Sayenko S.Yu., Tarasov R.V., Shylyayev B.A., Shyrokov B.M., Schur A.O. Ed. I.M. Neklyudov. Povodzhennja z vidprac'ovanim jadernim palivom ta radioaktivnimi vidhodami. Seria: Nuclear Energy [Spent nuclear fuel and radioactive waste management]. - K.: Naukova Dumka, 2006.-253 p. (in Ukrainian)

4. Akhmetzyanov V.R., Lashchenova T.N., Maximov O.A. Obrashhenie s radioaktivnymi othodami. [Radioactive waste management]. - M.: Energy, 2008. - 282 p. (in Russian)

5. Rudychev V.G., Alekhina S.V., Goloshchapov V.N., Zalyubovskiy I.I., Klimov S.P., Kostikov A.O., Luchnaja A.E., Matsevity Y.M., Pismenetsky S.A., Pyshnyj V.M., Sednev V.A., Tishhenko V.A. Bezopasnost' suhogo hranenija otrabotavshego jadernogo topliva. Seria: Safety of nuclear power plants. [The safety of dry storage of spent nuclear fuel]. - Kharkiv: HNU imeni V.N. Karazina, 2013. - 200 p. (in Russian)

6. Rukovodstvo po bezopasnosti RB-023-02: Rekomendacii po ustanovleniju kriteriev priemlemosti kondicionirovannyh radioaktivnyh othodov dlja ih hranenija i zahoronenija. [Security Guide RB-023-02: Guidelines for the establishment of acceptance criteria for conditioned radioactive waste storage and disposal]. Gosatomnadzor RF, introduced 1.03.2002. (in Russian)

7. Way K., Wigner E. Radiation from Fission Products // Phys. Rev. - 1946. - Vol. 70. - No. 1 - 2. - P. 115 - 130.

8. Gribin A.A., Pologih B.G Ostatochnoe energovydelenie produktov delenija ${ }^{235} \mathrm{U}$ teplovymi nejtronami. [The residual energy release of ${ }^{235} \mathrm{U}$ fission by thermal neutrons] // Atomic Energy. - 1981. - Vol. 51. - Iss. 1. - P. 16-19. (in Russian)

9. McNair A. Bannister F.J., Keith R.L.G., Wilson H.W. A measurement of the energy released as kinetic energy of $\beta$-particles emitted in the radioactive decay of the fission products of ${ }^{235} \mathrm{U} / /$ J. Nucl. Eng. - 1969. - Vol. 23. - No. 2. - P. 73.

10. Pismenetsky S.A., Pyshkin V.B., Rudychev V.G., Rudychev E.V. Ocenka ostatochnogo teplovydelenija otrabotavshego topliva VVER-1000 [Evaluation of the residual heat of VVER-1000 spent fuel] // The Journal of Kharkiv National University, physical series "Nuclei, Particles, Fields". - 2008. - No.794. - Iss.1(37). - P.69-72. (in Russian)

11. Bergelson B.R., Gerasimov A.S., Zaritskaya T.S., Tikhomirov G.V. Ostatochnoe jenergovydelenie i radiotoksichnost' aktinoidov i produktov delenija pri dlitel'nom hranenii otrabotavshego topliva VVER s povyshennym vygoraniem [The residual energy release and radiotoxicity of actinides and fission products with long-term storage of PWR spent fuel with high burnup]. // Atomic Energy. - 2007. - Vol.102. - Iss. 5. - P.292-296. (in Russian)

12. Kolobashkin V.M. et al. Radiacionnye harakteristiki obluchennogo jadernogo topliva: Handbook. [The radiation characteristics of irradiated nuclear fuel] Under the general editorship V.M. Kolobashkin. - M.: Energoatomizdat, 1983. - 382 p. (in Russian)

13. Gusev N.G. Zashhita ot ionizirujushhih izluchenij. Vol.1 [Protection against Ionizing Radiation]. - M.: Energoatomizdat, 1989. -512 p. (in Russian)

14. Mashkovich V.P., Kudryavtseva A.V. Zashhita ot ionizirujushhih izlucheni: Handbook. [Protection against Ionizing Radiation]. 4th Edition. - M.: Energoatomizdat, 1995. - 496 p. (in Russian)

15. Galanin A.D. Vvedenie v teoriju jadernyh reaktorov na teplovyh nejtronah [Introduction to the theory of nuclear reactors on thermal neutrons] 2nd ed., Rev. and Sub. - M.: Energoatomizdat, 1990. - 536 p. (in Russian) 